\begin{abstract}
Iranica
Abstracta Iranica Revue bibliographique pour le domaine irano-aryen

Volume 37-38-39 | 2018

Comptes rendus des publications de 2014-2016
\end{abstract}

\title{
John W. Watt, « Pensée grecque, controverses syriaques »
}

\section{Christelle Jullien}

\section{(2) OpenEdition \\ 12 Journals}

\section{Édition électronique}

URL : http://journals.openedition.org/abstractairanica/44330

DOI : 10.4000/abstractairanica.44330

ISBN : 1961-960X

ISSN : 1961-960X

Éditeur :

CNRS (UMR 7528 Mondes iraniens et indiens), Éditions de l'IFRI

Référence électronique

Christelle Jullien, « John W. Watt, «Pensée grecque, controverses syriaques » », Abstracta Iranica [En ligne], Volume 37-38-39 | 2018, document 17, mis en ligne le 30 décembre 2018, consulté le 02 octobre 2020. URL : http://journals.openedition.org/abstractairanica/44330 ; DOI : https://doi.org/ 10.4000/abstractairanica.44330

Ce document a été généré automatiquement le 2 octobre 2020.

Tous droits réservés 


\title{
John W. Watt, « Pensée grecque, controverses syriaques »
}

\author{
Christelle Jullien
}

\section{RÉFÉRENCE}

John W. Watt, « Pensée grecque, controverses syriaques » in Flavia Ruani (éd.). Les controverses religieuses en syriaque. Paris : Geuthner, 2016, p. 349-380. (Études syriaques 13)

L'A. analyse la portée des recueils de rhétorique et de philosophie - socles de l'enseignement scholastique durant l'Antiquité tardive - sur l'élaboration des traités de controverse par les écrivains syriaques. En dépit de l'absence de manuel syriaque de rhétorique avant le traité d'Antoine de Takrit au IXe siècle, il souligne que plusieurs textes syriaques à différentes époques comportent des éléments de rhétorique. De même, l'A. précise que la logique aristotélicienne fut parfois employée dans les controverses christologiques et par la suite dans les disputationes islamo-chrétiennes.

\section{AUTEURS}

\section{CHRISTELLE JULLIEN}

CNRS, Mondes iranien et indien, Paris 